\title{
鉄筋コンクリート造多層平面骨組の地震応答と柱梁接合部の耐震設計 EARTHQUAKE RESPONSE OF MULTI-STORY REINFORCED CONCRETE PLANE FRAME STRUCTURES AND SEISMIC DESIGN OF BEAM-COLUMN JOINTS
}

\author{
塩原＼cjkstart等*, 小林楓子**, 佐 藤 友 佳**, 楠原文雄 ${ }^{* * *}$ \\ Hitoshi SHIOHARA, Fuko KOBAYASHI, Yuka SATO \\ and Fumio KUSUHARA
}

\begin{abstract}
Earthquake response of multi-story reinforced concrete moment resisting frames are calculated considering the deformation of the beam-column joints modeled with rigid panels, uniaxial springs for concrete, steel and bond-slip representing the non-linear coupling of moments, axial forces and shear in members framing into the joint. The variation of the frames includes the column-to-beam strength ratio and the joint hoop reinforcement ratio which are neglected in the current design practice in Japan as structural design criteria affecting the seismic safety. Five synthesized base motions conformed to maximum considered design spectrum and five observed base motions are used. It is revealed that the design parameters of beam-column joint have significant influences. Particularly, the maximum story drift ratio significantly exceeds the current design criteria due to concentration of lateral deflection in some cases due to beam-column joint deformation caused by the mechanism known as joint hinging.
\end{abstract}

Keywords: reinforced concrete, moment resisting frame, beam-column joint, joint hinging, seismic design 鉄筋コンクリート，平面骨組，柱梁接合部，接合部降伏，而震設計

1. 序

現行の鉄筋コンクリート造骨組構造の耐震設計規定の妥当性は, 柱や梁等の部材の強度・剛性に関寸る研究と, 部材のモデルに基づ く架構モデルの動的地震応答に関する研究の蓄積に依拠している。 しかし，現在の架構モデルはすべての現象を再現できるわけではな い。例えば，柱がせん断破壊したあと軸方向に圧壊して架構が崩壊 する現象は，破壊における柱のせん断力と軸力の相互作用がモデル 化されていなければ再現できない。そこで，現行の耐震規定では， 部材の各種の構造規定や破壞規範を検定する保証設計を定めて, 架 構モデルが再現できない現象が起きる可能性を排除している。

しかし，部材レベルや部分架構レベルの実験が，試験体の配筋や 境界条件で現実の架構とは異なる結果，既往の研究では破壊の存在 自体が気づかれず，現行の耐震規定では排除できない破壊現象があ る。その一つが，柱梁接合部の接合部降伏と呼ばれる現象で，2016 年に発刊された本会の鉄筋コンクリート構造保有水平耐力規準 $(\text { (案) })^{1)}$ に, はじめて耐震設計上の注意が喚起されている。接合部降 伏が我が国の現行の耐震規定を満たしても起こることは, 鉄筋コン クリートの実大 RC4 層 ${ }^{2)}$ や実大 RC10 層 ${ }^{3)}$ の E-Defense 三次元実大 振動台実験で確認されている。ここで，接合部降伏とは，柱梁接合
部の接合部せん断余裕度が十分でも, 柱梁強度比が大きくなく, か つ, 接合部横補強筋が少ない場合に柱梁接合部に損傷が集中寸る柱 梁接合部の破壞現象である。我が国にはこれまでの耐震規定にこの タイプの破壊を防ぐ規定がなかったので，接合部降伏する架構の耐 震性能の詳しい検討が必要である。

本研究は, 大地震時の鉄筋コンクリート骨組の柱梁接合部の応力 と変形を考慮できるように開発された柱梁接合部のマクロエレメン 卜を用い, 梁曲げ降伏型に設計された骨組の地震応答を解析的に検 討し，今後の鉄筋コンクリート骨組構造の耐震設計や既存建物の耐 震診断における接合部降伏の課題を明らかにしようとしたものであ る。なお, 本研究は, 既発表の報告 ${ }^{4)}$ 5) を基に新たな検討を加えて 再構成したものである。

\section{2. 既往の研究}

1980 年代以降, 鉄筋コンクリート柱梁接合部部分架構の実験が増 え, それらが梁曲げ降伏型に設計されても, 多くの場合良好な紡錘 形の履歴特性が見られないことが広く知られるようになった。1990 年代には，その影響を地震応答解析で検討する研究が散見されるよ うになる。最初は, Takeda-slip モデル (6) に代表される履歴モデルが
* 東京大学大学院工学系研究科建築学専攻 教授. 工博

** 東京大学大学院工学系研究科建築学専攻修士課程 元大学院生

*** 名古屋工業大学社会工学専攻 准教授・博士 (工学)
Prof., Dept. of Architecture, School of Engineering, the University of Tokyo, Dr. Eng. Former Grad. Students, Dept. of Architecture, School of Engineering, the University of Tokyo

Assoc. Prof., Dept. of Architecture and Design, Civil Eng. and Industrial Management Eng. Nagoya Institute of Technology, Dr. Eng. 
用いられ，小谷ら ${ }^{7)}$, 芳村 $5^{8)}$, 壁谷澤ら ${ }^{91}$ は， 6 層ないし 12 層程 度のモデル建物の骨組解析を行っている。それらによれば，履歴モ デルのスリップ化の影響は小さく，それよりは地震動記録の特性の 影響のほうが大きいと指摘している。最近では, 前田ら ${ }^{10)}$ や, 和泉 ら ${ }^{11)}$ は, 耐力低下とスリップの両方を考慮する履歴モデルで同様の 検討を行って，やはりスリップの影響は小さいが，耐力低下の影響 は大きいとしている。それらはすべて全体降伏型の骨組構造物を対 象とし, 柱・梁は, 梁端部の回転ばねに履歴モデルを適用し, 柱梁 接合部は，剛ないし弾性としたもので，どちらも，柱梁接合部の上 下で節点回転角が連続することが仮定されている。また履歴モデル は, 簡単なルールで力と変形の関係を表しており, 履歴特性と実構 造物との対応が曖昧である問題がある。いずれにせよ，履歴モデル による影響は地震動の特性の影響より小さいことから, どの研究も， 現行設計の耐震規定の問題点を指摘する結論には至っていない。

同じ頃ヨーロッパや米国においては，1993 年のグアム地震や 1999 年のトルココジャエリ地震で, 柱梁接合部の破壊が注目される と, 既存建物の柱梁接合部の性能が問題となり, 2000 年代に入ると, 架構の耐震性能に及ぼす柱梁接合部の挙動の実験や解析が増えた。 典型的な例は, 2002 年のイタリアの Calvi らの研究で, 柱梁接合部 をシヤーパネルモデルでモデル化し 6 層 RC 骨組の動的解析を報告 している ${ }^{12)}$ 。しかし，シヤーパネルの復元力特性には，柱梁接合部 のせん断強度が用いられるので, 接合部せん断強度に余裕があれば, 接合部破壊は起こりえないモデルであり，接合部降伏は考慮されな い。

塩原らは, 文献 ${ }^{13)}$ で実用的な柱梁接合部のマクロエレメントを提 案し, 実験で得られる柱梁接合部の大地震時の挙動を再現できるこ とを検証し，ついで接合部降伏する柱梁接合部を含む 4 層鉄筋コン クリート造骨組の解析を行い, 多層架構の地震応答解析の可能性を 開いた。また，接合部降伏の復元力特性におけるピンチング現象と 耐力低下は，主筋の抜け出しによるものではなく，接合部内主筋の 降伏と接合部の斜めひび割れの開閉に伴うものであること ${ }^{13)}$ を示 した。また，接合部降伏における繰り返し載荷による耐力低下は， 斜めストラットのコンクリートバネの圧縮軟化により応力中心間距 離が短くなり抵抗モーメントが減少して起こることを明らかにし 14)，提案されたマクロエレメントで有効にモデル化できることを明 らかした。マクロエレメントでは柱梁接合部の寸法と配筋および材 料の力学特性に基づき設定できるので, 設計で取り扱う変数につい て広範囲に変動させて地震力を受け大変形領域に至る骨組の挙動を 模擬し比較検討することが可能となった。

\section{3. 研究方法}

現行の耐震規定に定められた静的地震力分布に対して, 必要な最 小限の保有水平耐力を有し, 柱梁接合部の接合部せん断耐力余裕度 を十分にとった鉄筋コンクリート造無限均等ラーメンのモデル建物 を試設計する。そこから 1 スパンを取り出した平面魚骨モデル ${ }^{13} に$ 置換し (Figure 1), 静的漸増載荷解析と非線形時刻歴地震応答解析 を行う。解析には, 筆者らが Matlab で開発したイン八ウスのプログ ラムを用いる。

通常の架構モデルでは, 柱や梁を弾性部材として端部に非線形の 回転バネを挿入した材端弾塑性バネモデルが用いられることが多い
が, 本研究で使われるのは, 柱梁接合部の応力と変形の関係におけ るモーメント・軸力・せん断力の相互作用をコンクリートと鉄筋の 一軸バネの組み合わせで表すマクロエレメントである。マクロエレ メントは, 柱主筋量と接合部補強筋量に応じて剛性や耐力が決まる。 そのため, 復元力特性を変化させるために, 履歴モデルのように復 元力特性のルールを恣意的に変化させる必要はない。例えば，接合 部補強量が少ないと柱梁接合部の強度が低下寸るが, 梁曲げ強度は 変化しないので, 接合部内の主筋に塑性変形が生じ柱梁接合部の変 形が増大し, 履歴特性は, マクロエレメントで表される接合部降伏 のピンチング性状の目立つ復元力特性が支配的になる。一方, 柱主 筇量や接合部補強量を多くすると柱梁接合部の強度が上がり, 柱梁 接合部の変形は減少し, 主に梁端部の塑性回転により架構の変形が 増大寸るので, 履歴特性は, 梁曲げ降伏の復元力が支配的なものに なる。このように, 柱主筋量を変えて柱梁強度比を変化させたり, 接合部横補強量を変化させたりすることにより, 架構の崩壊モード は, 接合部降伏から梁曲げ降伏まで連続的に変化することになる。 本研究は, このような原理により従来の架構モデルでは全く考慮さ れていない, 柱梁接合部内の配筋量と地震応答量を連続的に直接結 びつけその影響を定量化しており，既往の研究に前例がない。

既往の研究で述べたように, 地震応答は主に地震動記録の特性に 影響を受けることが指摘されている。そこで, 入力には, 同一の告 示スペクトルに適合する複数の模擬地震動を採用し, 観測記録地震 動も併用する。また, 後の解析結果で示すように, 特定層に層間変 形が集中する現象が見られることから, 特定層付近の層だけ配筋を 変更し接合部降伏が防止された場合, 層間変形の集中が緩和され, 梁曲げによる全体降伏型として安定した地震応答を得られるかにつ いても若干検討する。

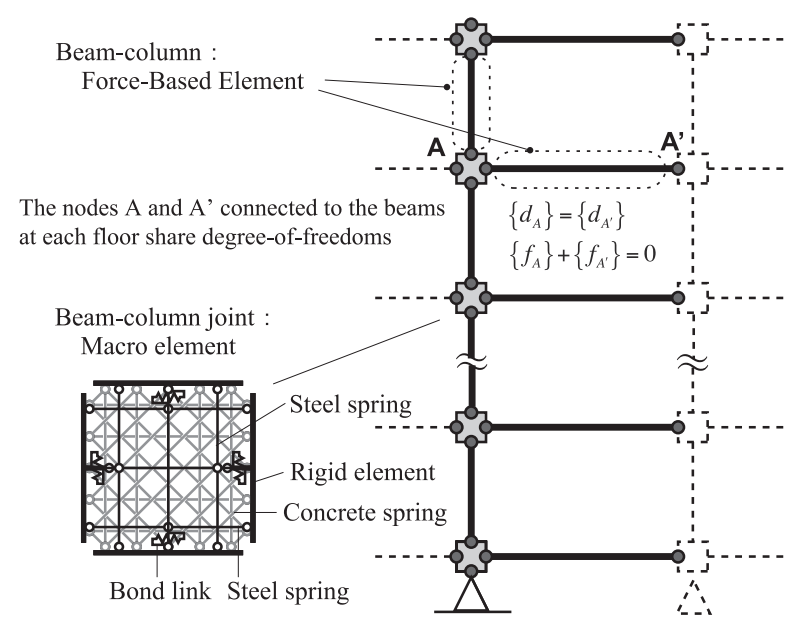

Fig. 1 Fish-bone model of multi-story frame structure incorporated with macro element of beam-column joint

\section{4. 建物の試設計とモデル建物}

モデル建物には，一般的な中低層 $\mathrm{RC}$ 純ラーメン建物を想定する。 スパンは $6000 \mathrm{~mm}$, 階高は $3500 \mathrm{~mm}, 1$ 層あたりの重量は $360 \mathrm{kN}$ (単 位床面積当たり $10.0 \mathrm{kN} / \mathrm{m}^{2}$ を仮定）とする。モデル建物の変数は, a) 層数, b) 柱梁強度比 $M_{R}$ と c) 接合部横補強比 $A_{j} f_{j y} / A_{t} f_{y}$ の組み合 わせとする。なお, 接合部横補強比は, 接合部横補強筋量 $A_{j} f_{j y}$ と梁 
の引張り主筋量 $A_{\mathrm{t}} \mathrm{f}_{\mathrm{y}}$ との比である。ここに, 接合部横補強筋量は横 補強筋の総断面積 $A_{j}$ と横補強筋降伏点 $\mathrm{f}_{\mathrm{j} y}$ との積, 引張主筋量は引張 主筋の総断面積 $A_{t}$ と引張主筋降伏点 $\mathrm{f}_{\mathrm{y}}$ との積とする。

変数の值は, 層数を $4 \cdot 8 \cdot 12$ の 3 種類, 柱梁強度比 $\mathrm{M}_{\mathrm{R}}$ を 1.2 , $1.5,2.0$ の 3 通り, 接合部横補強比を $\mathrm{A}_{\mathrm{j}} \mathrm{f}_{\mathrm{j} y} / \mathrm{A}_{\mathrm{t}} \mathrm{f}_{\mathrm{y}}$ を $0.2,0.4,0.6$ の 3 通りとし,それらを組み合わせた計 27 ケースのモデル建物を試設計 した。仮定した部材断面寸法・材料特性等の諸元は Table 1 に示した 通りで，以下にその配筋設計の方針を記す。

設計用の等価水平地震力は, 最下層の層せん断力係数が 0.3 の $\mathrm{Ai}$ 分布とし, 線形弾性骨組解析を行い部材応力を算出する。部材の曲 げ剛性は, 弾性剛性を基本とする。梁の曲げ剛性は, 梁長方形断面 の曲げ剛性 $\mathrm{E}_{\mathrm{c}} \mathrm{l}_{\mathrm{b}}$ に基づき，スラブによる曲げ剛性増大率 2.0 とひび 割れによる曲げ剛性低下率 0.5 を乗じた $\mathrm{E}_{\mathrm{c}} \mathrm{b}$ を用いる。柱の曲げ剛 性は，長方形断面の曲げ剛性 $\mathrm{E}_{\mathrm{c}} \mathrm{l}$ をを用いるが，断面一端にヒンジを 計画する最下階・最上階はひび割れによる曲げ剛性低下を考慮して $0.7 \mathrm{E}_{\mathrm{c}} \mathrm{c}_{\mathrm{c}}$ とする。

柱梁強度比 $M_{\mathrm{R}}$ は全層一定とする。梁主筋は上端と下端を等量と し, 梁端で曲げモーメントの応力值と断面の曲げ終局モーメントが ちょうど等しくなるように断面積を定める。ただし最下階と最上階 の梁主筋は，鉄筋比が $0.4 \%$ を下回る場合には，最低鉄筋量規定に従 い $0.4 \%$ を配筋する。最下階柱脚と最上階柱頭の主筋量は，線形骨組 解析による部材の曲げモーメントと軸力を考慮した柱断面の曲げ終 局モーメントが等しくなるよう定める。残りの柱頭柱脚では，柱梁 接合部の上下断面で柱主筋量を等しいものとして，柱の曲げ終局モ 一メントの和と梁曲げ終局強度時の節点モーメントの比が目標とす る柱梁強度比 $M_{R}$ と等しくなるよう定める。この際, 柱配筋は 4 辺 の主筋が同本数となるよう中段筋を決定する。柱主筋量の最小規定 に関しては, 8 層, 12 層建物では最上階付近で柱断面積の $0.8 \%$ を若 干下回るが，柱の最低主筋量の規定を適用しない。

接合部横補強比 $\mathrm{A}_{\mathrm{j}} \mathrm{f}_{\mathrm{j}} / \mathrm{A}_{\mathrm{t}} \mathrm{f}_{\mathrm{y}}$ は全層一定とする。これは, 接合部降伏 する柱梁接合部の強度は, 梁主筋量と接合部横補強筋量の比に比例

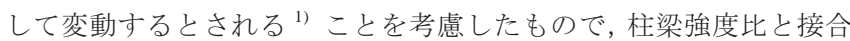
部横補強比が一定であれば，接合部降伏の起こりやすさもほぼ一定 になる。現行規定では接合部せん断補強筋比 $p_{w}$ は最小規定の $0.2 \%$ で決定されるが，本モデル建物では下層ほどいわゆる接合部せん断 補強筋比 $\mathrm{p}_{\mathrm{w}}$ が大きい。これは, 下層ほど梁引張主筋量が大きくな るためである。

接合部横補強比 $A_{\mathrm{j}} \mathrm{f}_{\mathrm{j} y} / A_{\mathrm{t}} \mathrm{f}_{\mathrm{y}}$ と接合部横補強筋比 $p_{\mathrm{w}}$ との関係について 以下に補足する。勒性保証型指針 ${ }^{16)}$ により算定した接合部横補強筋 比 $\mathrm{p}_{\mathrm{w}}$ の值は，接合部横補強比が 0.2 の場合で $0.06 \% \sim 0.28 \%, 0.4$ の 場合で $0.13 \% \sim 0.56 \%, 0.6$ の場合で $0.19 \% \sim 0.84 \%$ となる。この值は 十分に施工可能な範囲である。

柱梁接合部のせん断余裕度は, 勒性保証型指針 ${ }^{16)}$ のせん断強度式 を用いて算出して Table 1 に示してある。4 層建物のせん断余裕度 1.1〜3.3 と比較的小さいが仮定した柱断面が小さいためであり, 8 層建物と 12 層建物ではせん断余裕度は最小でも $1.6 \sim 5.2$ と充分な 余裕がある。すなわち，柱梁接合部はすべて現行の耐震規準のせん 断設計の規定を満たしている。

\section{5. 解析モデル}

柱, 梁と柱梁接合部のモデルは既発表 ${ }^{13)}$ と同様であるが，以下に その概略を述べる。

\section{1 柱と梁のモデル}

梁と柱は, 断面の図心を通り材軸方向にのみ広がりを有する太さ のない線とする。材軸方向に曲率を評価するための複数の積分点を 配置し, それらの点における応力分布は, 部材端部の応力と中間荷 重に適合するように仮定する Force-based Element ${ }^{17)}$ を用いる。材軸

Table 1 Properties of section, reinforcement and material (a) 4-story Frame

\begin{tabular}{|c|c|c|c|c|c|}
\hline FL & $\begin{array}{l}\text { Girder } \\
b \times D \\
\text { in } \mathrm{mm}\end{array}$ & $\begin{array}{c}\text { Column } \\
b \times D \\
\text { in mm }\end{array}$ & \begin{tabular}{|c|} 
Tensile \\
reinforcement \\
ratio of girder \\
$p_{t}^{*}$ \\
in $\%$ \\
\end{tabular} & $\begin{array}{c}\text { Concrete } \\
\text { compressive } \\
\text { Strength } \\
\sigma_{B} \\
\text { in } \mathrm{N} / \mathrm{mm}^{2}\end{array}$ & $\begin{array}{l}\text { Joint shear } \\
\text { capacity/de } \\
\text { mand ratio }\end{array}$ \\
\hline $\mathrm{RF}$ & $400 \times 650$ & - & 0.40 & \multirow{5}{*}{27} & 3.3 \\
\hline $4 \mathrm{~F}$ & \multirow{3}{*}{$400 \times 650$} & \multirow{4}{*}{$550 \times 550$} & 0.78 & & 1.8 \\
\hline $3 \mathrm{~F}$ & & & 1.13 & & 1.3 \\
\hline $2 \mathrm{~F}$ & & & 1.32 & & 1.1 \\
\hline $1 \mathrm{~F}$ & $750 \times 2000$ & & 0.40 & & - \\
\hline
\end{tabular}

* SD345 for longitudinal reinforcements and SD295 for joint hoops respectively

(b) 8-story Frame

\begin{tabular}{|c|c|c|c|c|c|}
\hline FL & $\begin{array}{c}\text { Girder } \\
b \times D \\
\text { in } \mathrm{mm}\end{array}$ & $\begin{array}{c}\text { Column } \\
b \times D \\
\text { in } \mathrm{mm}\end{array}$ & \begin{tabular}{|c|} 
Tensile \\
reinforcement \\
ratio of girder \\
$p_{t}^{*}$ \\
in $\%$ \\
\end{tabular} & $\begin{array}{c}\text { Concrete } \\
\text { compressive } \\
\text { Strength } \\
\sigma_{B} \\
\text { in } \mathrm{N} / \mathrm{mm}^{2} \\
\end{array}$ & $\begin{array}{c}\text { Joint shear } \\
\text { capacity/ } \\
\text { demand } \\
\text { ratio }\end{array}$ \\
\hline $\mathrm{RF}$ & \multirow{3}{*}{$400 \times 800$} & - & 0.40 & \multirow{4}{*}{30} & 4.8 \\
\hline $8 \mathrm{~F}$ & & \multirow{3}{*}{$700 \times 750$} & 0.58 & & 3.3 \\
\hline $7 F$ & & & 0.82 & & 2.4 \\
\hline $6 \mathrm{~F}$ & \multirow{2}{*}{$450 \times 800$} & & 0.94 & & 1.9 \\
\hline $5 \mathrm{~F}$ & & \multirow{5}{*}{$750 \times 750$} & 1.09 & \multirow{5}{*}{36} & 1.8 \\
\hline $4 \mathrm{~F}$ & \multirow{3}{*}{$500 \times 800$} & & 1.13 & & 1.7 \\
\hline $3 \mathrm{~F}$ & & & 1.21 & & 1.6 \\
\hline $2 \mathrm{~F}$ & & & 1.18 & & 1.6 \\
\hline $1 \mathrm{~F}$ & $750 \times 2000$ & & 0.40 & & - \\
\hline
\end{tabular}

* SD390 for longitudinal reinforcements and SD345 for joint hoops respectively

(c) 12-story frame

\begin{tabular}{|c|c|c|c|c|c|}
\hline FL & $\begin{array}{c}\text { Girder } \\
b \times D \\
\text { in } \mathrm{mm}\end{array}$ & $\begin{array}{c}\text { Column } \\
b \times D \\
\text { in } \mathrm{mm}\end{array}$ & $\begin{array}{c}\text { Tensile } \\
\text { reinforcement } \\
\text { ratio of girder } \\
p_{t}^{*} \\
\text { in } \%\end{array}$ & $\begin{array}{c}\text { Concrete } \\
\text { compressive } \\
\text { Strength } \\
\sigma_{B} \\
\text { in } \mathrm{N} / \mathrm{mm}^{2}\end{array}$ & $\begin{array}{l}\text { Joint shear } \\
\text { capacity/ } \\
\text { demand } \\
\text { ratio }\end{array}$ \\
\hline $\mathrm{RF}$ & \multirow{4}{*}{$500 \times 900$} & - & 0.40 & 30 & 5.2 \\
\hline $12 \mathrm{~F}$ & & \multirow{4}{*}{$700 \times 850$} & 0.41 & 50 & 4.6 \\
\hline $11 \mathrm{~F}$ & & & 0.59 & & 3.4 \\
\hline $10 \mathrm{~F}$ & & & 0.74 & 23 & 2.7 \\
\hline $9 \mathrm{~F}$ & \multirow{4}{*}{$550 \times 900$} & & 0.81 & נJ & 2.3 \\
\hline $8 \mathrm{~F}$ & & \multirow{4}{*}{$800 \times 850$} & 0.91 & & 2.1 \\
\hline $7 \mathrm{~F}$ & & & 1.01 & & 2.0 \\
\hline $6 \mathrm{~F}$ & & & 1.09 & 36 & 1.9 \\
\hline $5 \mathrm{~F}$ & \multirow{4}{*}{$600 \times 900$} & & 1.08 & & 1.8 \\
\hline $4 \mathrm{~F}$ & & \multirow{4}{*}{$850 \times 850$} & 1.14 & \multirow{4}{*}{42} & 1.9 \\
\hline $3 \mathrm{~F}$ & & & 1.16 & & 1.8 \\
\hline $2 \mathrm{~F}$ & & & 1.11 & & 1.9 \\
\hline $1 \mathrm{~F}$ & $750 \times 2000$ & & 0.40 & & - \\
\hline
\end{tabular}

* SD390 for longitudinal reinforcements and SD345 for joint hoops respectively 
方向の曲げモーメント分布は, 柱は直線分布とし, 梁は一様鉛直荷 重を考慮した放物線分布とする。積分点の数は，部材を材軸方向に 6 等分する点と部材端の 7 点とし, 数值積分は台形則による。各積 分点には, 平面保持を仮定する断面の曲げ解析より求めたひび割れ 点と降伏点で表される 3 折れ線のモーメント-曲率関係を与える。降 伏後の剛性は一律に初期剛性の $0.15 \%$ とする。繰り返し載荷時のモ 一メント-曲率関係は，3 折れ線のスケルトンカーブで定義される履 歴モデルを用いて表し，梁にはN ormal-Trilinear モデル，柱にはそれ より剛性低下のより大きなモデルとして Takeda モデル ${ }^{18)}$ と同じル ールを用いる。柱と梁の変形には曲げ変形のみを考慮し, 柱では幾 何学的非線形を考慮してP-A効果を取り入れる。なお, 断面の曲げ 解析の材料特性は, コンクリートにK ent \& Park モデルを仮定し,

圧縮強度時の歪度を $0.2 \%$ とする。鉄筋には弾塑性モデルを仮定する。

\section{2 柱梁接合部のモデル}

柱梁接合部は, 梁端部と柱端部の柱梁接合部フェースにおける平 面保持仮定を表す 4 枚の剛板と剛板間をつなぐ 4 方向のコンクリー トバネ，主筋および接合部横補強筋を表す鉄筋ばね，コンクリート と主筋の付着を表す一軸ばねから構成されるマクロエレメントで表 す。コンクリートの分割数は, 鉛直水平の各方向で 8 , 斜め方向ば 水は各方向で 16 とする。マクロエレメントの寸法は, 水平長さは柱 せい，鈆直長さは梁せいとそれぞれ等しいものとする。接合部内の 主筋量と接合部補強筋は, 等量の鉄筋ば政に置換する。柱梁接合部 内においてコンクリートにはひび割れがおきても剥落や落下は起こ らず，応力歪関係により定まる圧縮力の応力伝達機構が最後まで保 持されるものとする。

\section{3 マクロエレメントの構成材料の構成則}

柱梁接合部のマクロエレメントを構成する一軸ばねの構成則は 材料の一軸力学特性に基づいて設定する。それらの履歴モデルを Figure 2 に示す。

a) コンクリート コンクリートは，圧縮側はK K ent \& Park モデル とし, 圧縮強度時の歪度を $0.2 \%$ とする。拘束効果による増大係数 $\mathrm{K}$ は 1.0 と寸る。下り勾配 $Z_{\mathrm{m}}$ は圧縮破壊エネルギーが一定值 ${ }^{19)}$ にな るようにコンクリートの骨材径とバネの長さを考慮して定める。こ こで, 最大骨材寸法は $25 \mathrm{~mm}$ とする。引張り側は線形弾性とし, 引 張り強度 $f_{t}\left(\mathrm{~N} / \mathrm{mm}^{2}\right)$ は圧縮強度 $\sigma_{B}\left(\mathrm{~N} / \mathrm{mm}^{2}\right)$ から次式で求める。

$$
f_{t}=0.5 \sqrt{\sigma_{B}} \quad\left(\mathrm{~N} / \mathrm{mm}^{2}\right)
$$

b) 鉄筋 接合部内の鉄筋を表すばねは二折れ線であらわす。履歴 特性は, Figure 2(b)のようにバウシンガー効果を 2 折れ線で簡略的 にモデル化する。降伏後剛性低下率は $0.1 \%$ とし, 歪硬化は考えない。

c) 付着 モデル建物では梁通し主筋の付着設計が行われ，付着破 壊はないと仮定して, 通し主筋の接合部内の付着ばねは弾性とする。 弾性剛性 $k$ は,

$$
k=2.94 \sigma_{B}^{2 / 3}\left(1+\frac{\sigma_{0}}{\sigma_{B}}\right) \quad\left(\mathrm{N} / \mathrm{mm}^{3}\right)
$$

で求める。ここに， $\sigma_{B}$ : コンクリートの圧縮強度 $\left(\mathrm{N} / \mathrm{mm}^{2}\right), \sigma_{0}$ : 柱 の軸応力度 $\left(\mathrm{N} / \mathrm{mm}^{2}\right)$ 。

\section{4 架構のモデル化と境界条件}

梁要素と柱要素の両端部の節点と柱梁接合部のマクロエレメント の剛板は自由度を共有する。梁の右端節点（Figure 1 の $A^{\prime}$ 点）の変 位は, 絶対鉛直変位が拘束されないように, 通常行われるような水 平ローラー支持とはせず, 柱梁接合部パネルの左辺上の節点 (Figure 1 の $\mathrm{A}$ 点）の水平・鉛直・回転の寸心゙ての変位成分が等しくなるよ う自由度を共有させる。最下階柱梁接合部の下端はピン支持とする。

\section{5 静的繰返し漸増振幅載荷解析}

静的繰返し漸増振幅載荷解析は, 頂部の水平変位制御の正負繰り 返しで行い, 各ピーク同一振幅を 2 回ずつ繰り返す。振幅はピーク 時の頂部変位が建物高さの $0.1 \%, 0.5 \%, 1 \%, 1.5 \%, 2 \%$ とする。外 力分布形は一定で $\mathrm{A}_{i}$ 分布と寸る。以下, 層間変形角は層間変位をそ の層の高さで除した值とし, 頂部の部材角は頂部水平変位を建物高 さで除した值とする。

\section{6 動的時刻歴地震応答解析}

運動方程式の数值積分にはニューマーク $\beta$ 法を用いる。積分時間 刻みは 1/1000 秒とし, Newton-Raphson 法を用いて不釣り合い力が 小さくなるよう収束計算を行う。質点を付帯させる各階の並進の代 表変位は, 柱梁接合部パネルの上辺と下辺の水平変位の平均, 柱梁
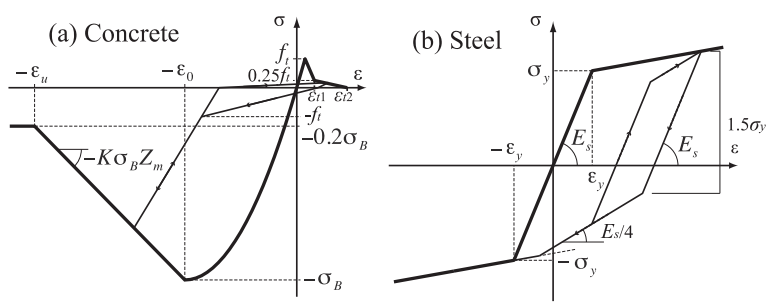

Fig. 2 Hysteresis models for concrete and steel spring

\begin{tabular}{|c|c|c|c|c|c|c|c|}
\hline \multirow[b]{3}{*}{$\begin{array}{l}\text { \# of } \\
\text { floor }\end{array}$} & \multirow[b]{3}{*}{$M_{R}$} & \multicolumn{6}{|c|}{$A_{j} f_{j y} / A_{t} f_{y}$} \\
\hline & & \multicolumn{2}{|c|}{0.2} & \multicolumn{2}{|c|}{0.4} & \multicolumn{2}{|c|}{0.6} \\
\hline & & \multicolumn{3}{|c|}{$\begin{array}{l}\text { Type of collapse } \\
\text { mechanism }\end{array}$} & \multicolumn{3}{|c|}{$\begin{array}{c}\text { Equivalent damping } \\
\text { factor at 2\% drift ratio } \\
\text { Cyclic decay of strength } \\
\text { at 2\% drift ratio }\end{array}$} \\
\hline \multirow{6}{*}{4} & \multirow{2}{*}{1.2} & \multirow{2}{*}{ II } & 0.10 & \multirow{2}{*}{ II } & 0.12 & \multirow{2}{*}{ II } & 0.15 \\
\hline & & & 0.74 & & 0.72 & & 0.67 \\
\hline & \multirow{2}{*}{1.5} & \multirow{2}{*}{ II } & 0.09 & \multirow{2}{*}{ II } & 0.11 & \multirow{2}{*}{ III } & 0.25 \\
\hline & & & 0.78 & & 0.77 & & 0.99 \\
\hline & \multirow{2}{*}{2.0} & \multirow{2}{*}{ II } & 0.07 & \multirow{2}{*}{ II } & 0.09 & \multirow{2}{*}{ III } & 0.28 \\
\hline & & & 0.81 & & 0.79 & & 0.99 \\
\hline \multirow{6}{*}{8} & \multirow{2}{*}{1.2} & \multirow{2}{*}{ I } & 0.20 & \multirow{2}{*}{ I } & 0.23 & \multirow{2}{*}{ I } & 0.24 \\
\hline & & & 0.73 & & 0.64 & & 0.65 \\
\hline & \multirow{2}{*}{1.5} & \multirow{2}{*}{ II } & 0.09 & \multirow{2}{*}{ II } & 0.31 & \multirow{2}{*}{ III } & 0.35 \\
\hline & & & 0.85 & & 0.93 & & 1.00 \\
\hline & \multirow{2}{*}{2.0} & \multirow{2}{*}{ II } & 0.05 & \multirow{2}{*}{ II } & 0.31 & & 0.38 \\
\hline & & & 0.90 & & 0.99 & 111 & 1.00 \\
\hline & & & 0.22 & & 0.30 & & 0.33 \\
\hline & 1.2 & 1 & 0.62 & 1 & 0.64 & 1 & 0.61 \\
\hline 27 & 15 & 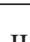 & 0.12 & 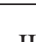 & 0.29 & 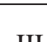 & 0.41 \\
\hline 12 & 1.0 & $\pi$ & 0.89 & 11 & 0.98 & 111 & 1.00 \\
\hline & 20 & 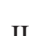 & 0.05 & II & 0.29 & 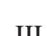 & 0.43 \\
\hline & L.U & $\|$ & 0.89 & 11 & 0.98 & 111 & 1.00 \\
\hline
\end{tabular}

Table 2 Collapse mechanism by static analysis

I : joint hinging $\&$ column sway, II : joint hinging $\&$ beam sway, III : beam hinging 
接合部パネルの左辺と右辺の鉛直変位の平均とする。つまり，層の 慣性質量は，鉛直方向を梁端部の節点に等分して，水平方向を柱端 部の節点に等分してそれぞれ与える。減衰は, 瞬間剛性比例型とし, 弾性 1 次固有周期に対して $3 \%$ とする。

\section{6. 静的増分解析 \\ 6.1 架構の崩壊型}

計 27 ケースのモデル建物の静的繰り返し漸増解析を, 接合部降伏 し特定層に層間変形が集中する層崩壊型（タイプI），接合部降伏す る全体崩壊型（タイプI），および, 梁曲げ降伏する全体崩壊型（タ イプIII）に分類した。架構としての接合部降伏の有無のクライテリ アは，最下階と最上階を除いてほとんどの柱梁接合部が接合部降伏 していない場合をタイプII とし, それ以外を, タイプ।もしくはタ イプ|I とした。ここで，柱梁接合部内で柱中段筋を除いて過半の柱 主筋と梁主筋が降伏し，かつ，柱梁接合部の変形角が 0.5\%程度を超 えたものを接合部降伏したものとする。分類の結果をTable 2 に示 す。

タイプ| となったのは， 8 層と 12 層で柱梁強度比が 1.2 の計 6 ケ ースである。タイプ।では, 層間変形の集中が 2 3 層目に起こり, 最大層間変形角は $6 \%$ を超えた。残りの層は大きな塑性変形は経験 しない。ほとんどの柱梁接合部内の梁と柱の主筋の多くが降伏し, 接合部降伏が発生している。すべての層で層間変形に柱梁接合部の 変形が占める割合は圧倒的に大きい。

タイプ॥ となったのは，4 層建物では柱梁強度比が 1.2, 1.5 と 2.0, 8 層建物と 12 層建物では柱梁強度比が 1.5 と 2.0 で接合部横補 強比が 0.2 及び 0.4 の計 15 ケースである。タイプ।と異なり, 層間 変形が上下方向に緩やかに分布し，特定層での変形集中はない。最 下階と最上階を除いてほとんどの柱梁接合部で接合部降伏が発生し, 層間変形に占める柱梁接合部の変形はかなり大きい。柱梁接合部内 の梁主筋と柱主筋もしくは梁主筋の多くが降伏しているが，その塑 性化の程度にはケースにより違いがある。

タイプIII は, 柱梁強度比が 1.5 または 2.0 , かつ, 接合部横補強 比が 0.6 の 4 層, 8 層, 12 層建物の計 6 ケースである。タイプ || と 同様に特定層での層間変形の集中はない。柱梁接合部の変形角はほ ぼ全層で $0.5 \%$ 程度であり，層間変形に占める変形はほとんどが梁の 曲げ降伏によるものである。なお，どのタイプにおいても，接合部 横補強筋はすべてのケースにおいて降伏していた。

\section{2 全体架構の履歴形状}

静的繰返し漸増載荷解析時の頂部の部材角とベースシヤ係数の履 歴形状をFigure 3(a) (b) (c)に示す。Table 2 には, 層間変形角 2\%時の 等価粘性減衰係数と, 耐力低下率の值が示されている。ここに耐力 低下率は，最大耐力を基準とした層間変形 $2 \%$ 時のピークの耐力の 割合である。各層の最大層間変形角の具体の分布形状については, 後述の Figure 8 内に示してあり，そこで動的応答と比較して述べる。

復元力特性と履歴形状の傾向は前節で分類したタイプと明確な対 応関係が見られたので崩壊タイプとの関係について述べる。

まず，最大ベースシヤ係数は，想定通り概衫 0.3 であることがわ かる，しかし，タイプII，タイプ川，タイプ|の順に少しずつ小さ くなっている。これは, タイプ।, I は接合部降伏の強度が梁曲げ 降伏より強度が低いことが原因である。

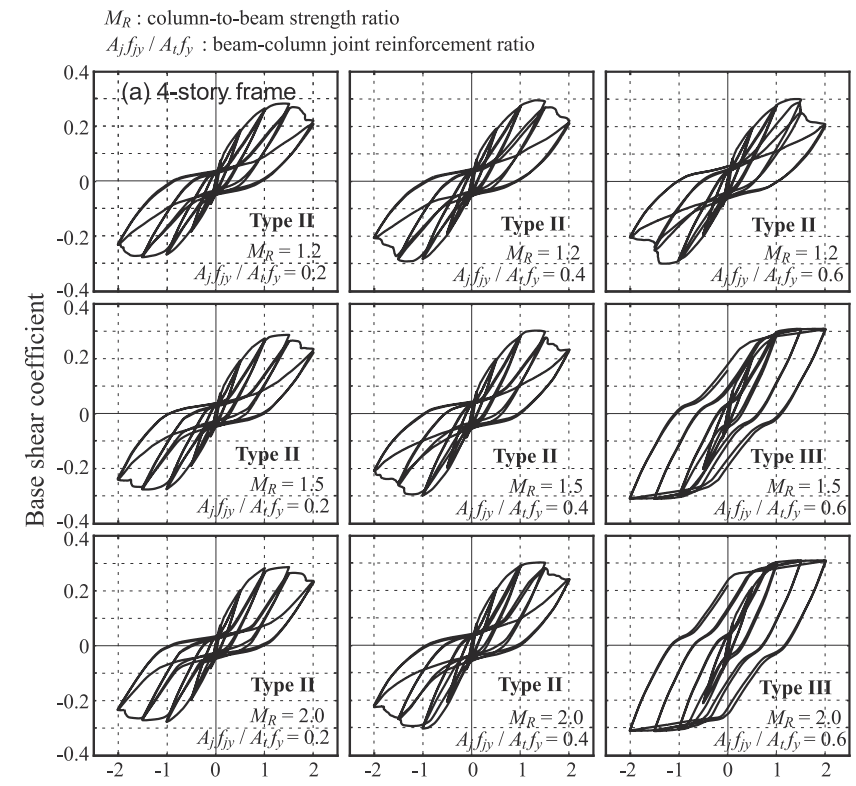

Deflection angle at roof floor,$\times 10^{-2} \mathrm{rad}$.
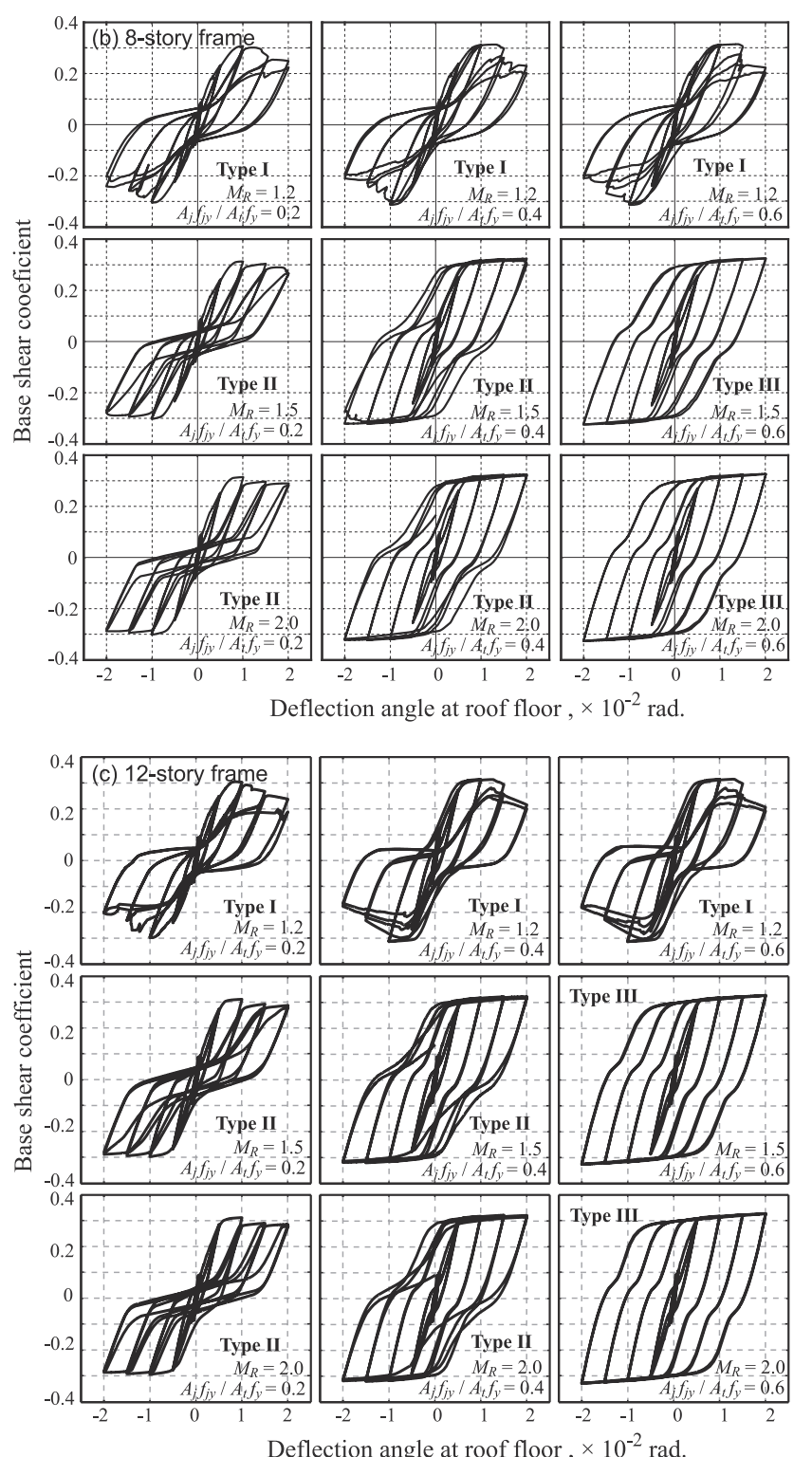

Fig. 3 Base shear-average story drift relation 
タイプ|では, 層間変形角 $0.5 \%$ の゚ークの復元力が最も小さいこ とからわかるように, 降伏前の剛性が相対的に低い。また, 繰り返 しによる耐力低下が顕著で，ピンチング傾向があるがやや太った履 歴形状となっている。8 層よりは 12 層でその傾向は顕著である。履 歴エネルギー吸収のほとんどは, 特定層の層崩壊による履歴性状を 反映している。すなわち，接合部の斜めひび割れの開閉による接合 部補強筋の塑性変形がかなり履歴エネルギーを消費していると考え られる。そのため接合部補強量が多いほど等価粘性減衰が大きい。 耐力低下率は 0.7 程度である。層間変形角 $2 \%$ 時の等価粘性減衰は 20\%から 30\%程度で比較的大きい。これは, 変形集中層で塑性率が 極めて高いためであろう。

タイプ II では, 接合部降伏する柱梁接合部の部分架構実験で見ら れる特徵であるスリップ型の履歴特性が良く再現されている。柱梁 接合部横補強比が 0.2 では, 耐力低下率は 0.8 から 1.0 程度で等価粘 性減衰定数は $10 \%$ 程度である。タイプ川でも柱梁接合部横補強比が 0.4 になると, 柱梁接合部の横補強量の増加により履歴形状はスリ ップ型から紡鍾形に変化し, 等価粘性減衰率は $30 \%$ 程度に増大寸る。 寸なわち，横補強筋量に敏感である。

タイプIII では，良好な紡錘形の履歴形状が得られ繰り返しによ る耐力低下はない。1988 年にニュージーランドのカンタベリー大学 が報告した，NZS3101 規定の通り設計された Unit1 の実験 ${ }^{201}$ のよ うに理想的な紡錘型の復元力特性となっている。スリップ性状やピ ンチング性状は全く見られない。等価粘性減衰は 25\%から 40\%程度 と大きく, 振幅が増大しても耐力低下はなく, 安定した履歴特性と なっている。

\section{7. 動的地震応答}

これまでの節で説明した 27 ケースのモデル建物の動的地震応答 について，静的解析の結果から分類したタイプ別に述べる。

\section{1 入力地震動}

入力地震動は, 告示の極めて稀な大地震の地震動の加速度応答ス ペクトルに表層地盤の増幅率を乗じたスペクトルに適合するように 正弦波合成法により作成した継続時間 60 秒の模擬地震動 5 波を基本 とする。ここに, 表層地盤の増幅率は第二種地盤のものとしており, 模擬地震動のフーリエ位相には, El Centro, Hachinohe, Kobe, Taft, Tohoku の各観測波 5 波から得られたものを用いる。さらに 8 層建 物では最大速度を 100 kine に基準化した観測波 5 波の応答も計算し 模擬地震動の応答と比較する。

Figure 4 に模擬地震動 5 波および最大速度を 100 kine に基準化し た観測波 5 波の減衰 $5 \%$ の最大絶対加速度応答スペクトルを示す。 なお，固有值解析により算出した弾性一次固有周期は，4層，8 層 12 層でそれぞれ，0.63 秒，0.57 秒，0.65 秒となった。いずれも告示 スペクトルのコーナー周期より小さい。 4 層建物の固有周期が 8 層 より長いのは, 部材断面が相対的に小さいことが原因と考えられる。

\section{2 最大応答変位と層間変形の集中}

\section{(1) 時刻歴応答}

タイプ|とタイプ II では，大地震の入力時に特定層に層間変形が 増大し集中している。一例として，8層建物に EI Centro 位相の模擬 地震動入力した場合について, タイプ|とタイプ II の各層の水平変 位の時刻歴波形をFigure 5 に比較する。タイプ।では 8 秒以降，振
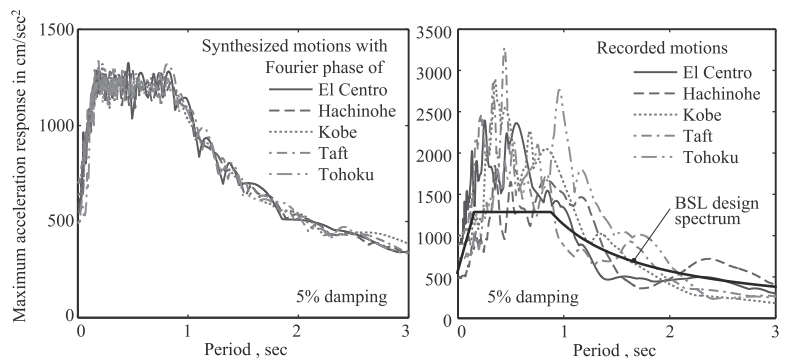

Fig. 4 Response acceleration spectra of base input motions

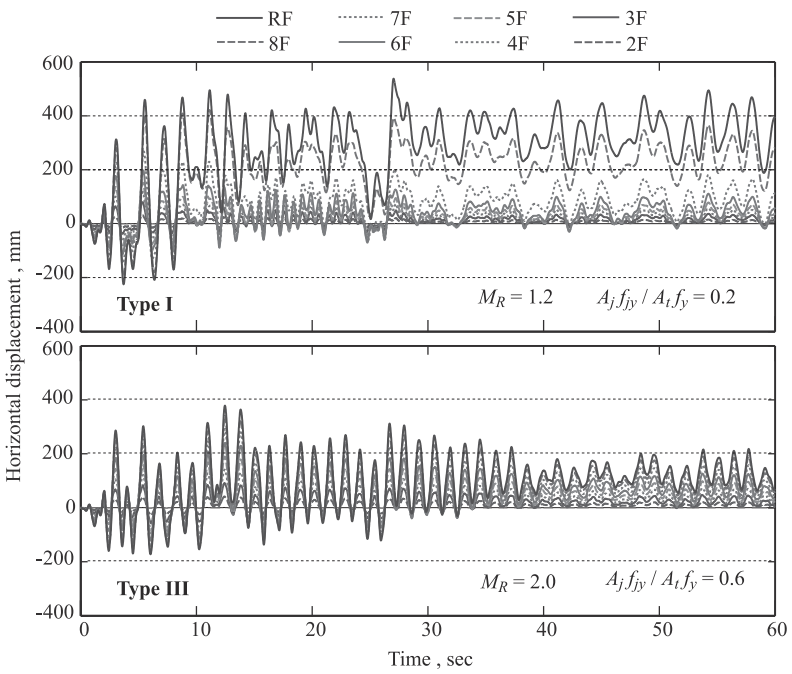

Fig. 5 Time history of floor lateral displacement

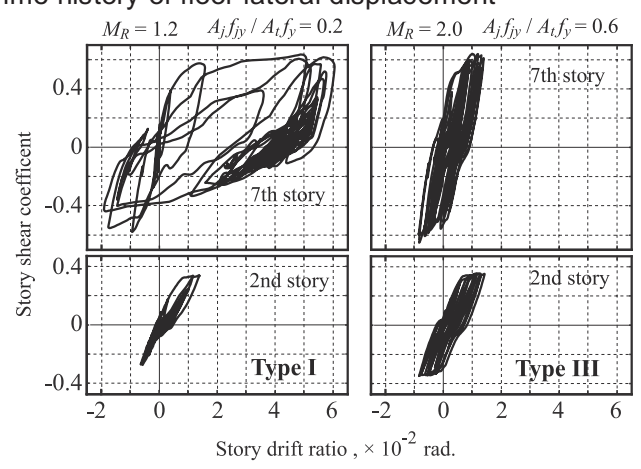

Fig. 6 Story shear coefficient vs. story drift ratio relation of 8-story frame structure

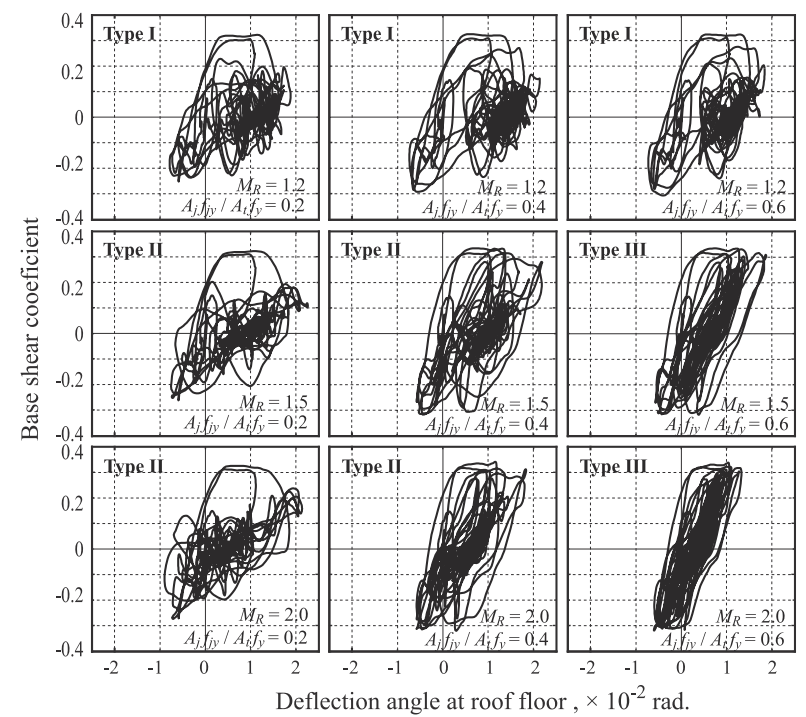

Fig. 7 Base shear coefficient vs. average deflection angle relation of 8-story frame structure 
幅が一方向に流れ始め, その後 7 層目から上の層でむち振り現象が 発生し, 大きな残留変形が見られる。タイプ川 の建物では, 各階 の線の間隔は常にほぼ均等で, 特定の層間変形がある時点から増大 するようなことはなく一定の変形モードを保ち安定した振動性状を 示した。Figure 6 は, Figure 5 の 2 ケースの応答における 7 層目と 2 層目の層せん断力係数と層間変形角の関係を示している。タイプ। では， 7 層目で層間変形角が $6 \%$ に達しており，2 層目は層間変形 角は $1 \%$ 程度で小さい。タイプ川は, それとは対照的に 2 層目も 7 層目も最大層間変形角が 1.5\%程度で塑性率 2 程度である。このよう に, 耐震規定上は同じ性能と判定される骨組であっても地震応答は 全く異なっている。

Figure 7 は, 8 層のモデル建物 9 ケース寸べての El Centro 位相模 擬地震動入力時の頂部の部材角とベースシヤ係数の関係を示してい る。どのケースの頂部の部材角も最大值は $2 \%$ 程度であり，大きな 違いはない。タイプIIの中には履歴形状がタイプIIIのように優れ たものも含まれるが，頂部の最大部材角はタイプ|とほとんど違い がない。履歴形状に優れるタイプ川I の最大值は $1.3 \%$ と若干少ない が, 履歴性状が応答変形への影響は大きくない点は既往の研究で指 摘された通りである。つまり, 履歴形状の違いによる最大応答変位 への影響は少ない。ここではデータを示していないが，他の模擬地 震動の入力でもこの傾向は同じである。

\section{(2) 最大層間変形角}

層間変形角は，耐震設計において設計の妥当性を判定するために 極めて重要な指標である。そこで次に同じ応答スペクトルを有する 模擬地震動の位相角特性の違いが, 最大層間変形角に及ぼす影響を 検討する。Figure 8 に全 27 ケースの模擬地震動 5 波の入力時の動的 応答における, 各層の最大層間変形角の最大值と地震動 5 波の平均 值が示してある。これと併せて, 静的漸増載荷解析の $2 \%$ 終了時の 最大層間変形角および柱梁接合部の変形角の分布も示している。こ こに, 柱梁接合部の変形角とは, 柱梁接合部のマクロエレメントの 柱側と梁側の剛板の回転角の和のことで柱梁接合部の変形による層 間変形角への寄与分に相当する。図中の丸記号の色は，黒が柱梁接 合部内の主筋が半数以上降伏したもの, 白が半数未満の降伏であっ たものを表す。

以下，最大層間変形角は，4 層・8 層・12 層でそれぞれ異なる傾 向が見られたため, タイプと層数に着目して解析結果について述心゙ る。4 層建物の最大層間変形角は地震動によっては $8 \%$ を大き超え た。8層建物と 12 層建物ではそれほど大きくはない。これは，どの 場合も建物が長周期化して変位一定領域の応答に入ったため, 建物 高さに反比例して層間変形角が大きくなったものと考えられる。次 に，崩壊機構のタイプ別の応答について述べる。

タイプ|の動的応答では, 最上層より少し下の層の最大層間変形 角が大きくなった。8 層骨組では, 模擬地震動入力時には 7 層目に 最大層間変形角が集中した。12 層骨組では, 模擬地震動入力時には 11 層目に最大層間変形角が集中した。一方, 静的解析ではどちらも 下から 2，3 層目に層間変形角が集中しており集中位置は異なった。

タイプ I は, 柱梁強度比が大きく接合部横補強筋量が多いほど変 形の集中が回避され，結果として最大層間変形角も小さくなった。 ただし, EI Centro 位相の入力の場合のように, 最上階付近で地震動 によっては層間変形が集中するケースも一部に見られた。

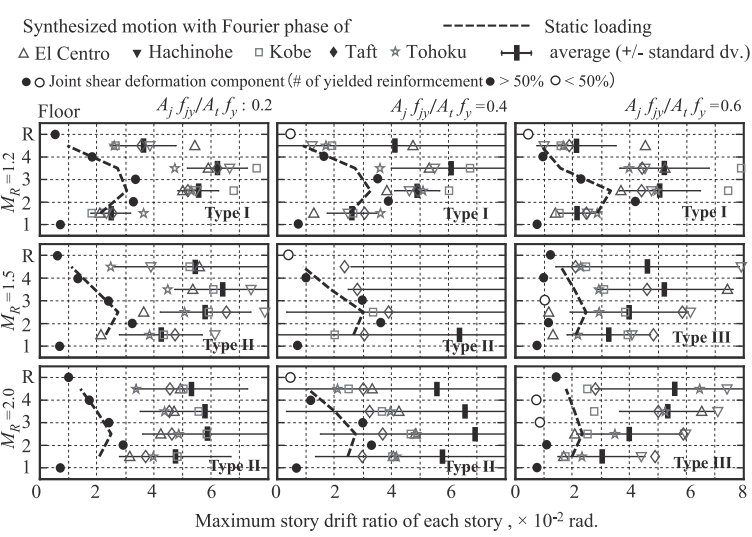

(a) 4-story structure

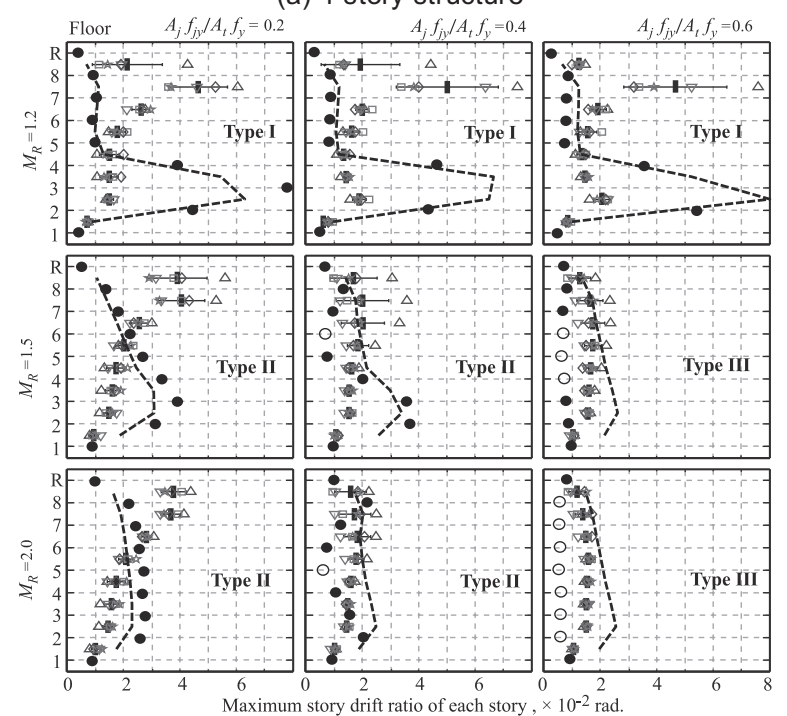

(b) 8-story structure

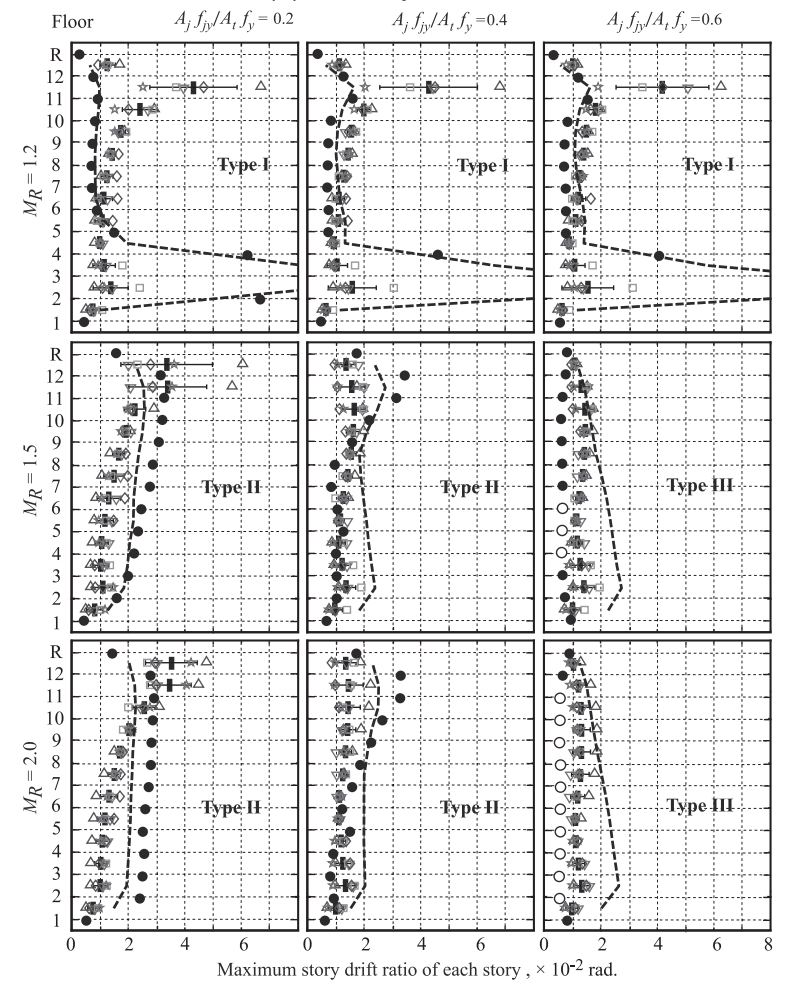

(c)12-story structure

Fig. 8 Attained maximum story drift in static and dynamic responses with excitation of 5 synthesized ground motions 
タイプ III であっても， 4 層建物では最大層間変形角が平均して $4 \%$ から $5 \%$ と大きくなった。8 層建物や 12 層建物では, 最大層間変 形角の平均值は $1 \%$ から $2 \%$ で, 層間変形分布は概放一様であり, 模 擬地震動の種類によらずばらつきは小さくなった。また，タイプ川 では, 柱梁接合部の最大変形角は 4 層建物では最大で $1.0 \%, 8$ 層建 物と 12 層建物では最大で $0.5 \%$ であり，接合部変形が弾性範囲にと どまって，梁の曲げ降伏により一定の振動モードを保つ安定した応 答であることが確かめられた。

これらをまとめると次のことが言えよう。すなわち, タイプ|や, タイプ\|では，層間変形が集中する層が静的解析と異なる結果とな った。また，応答スペクトル形状が同じ模擬地震動であっても，地 震動の位相角分布により最大層間変形角は変化する。これでは，限 界耐力計算等で用いられる簡易な地震応答の推定で静的解析の変形 分布から層間変形分布を予測することは困難であろう。これは，接 合部降伏する柱梁接合部を含む架構の特性といえよう。一方，タイ プIIIにおいては, 応答変位の分布形状は静的解析の結果に比較的 近く，応答スペクトル形状が同じであれば，模擬地震動によらず応 答変位のばらつきは小さく安定しているものと言える。これは，架 構が梁曲げ降伏型であるために, 確実に各層の層間変位が一様とな ったもので，それに加えて良好な履歴減衰特性による応答の低減も ある程度影響しているものと考えられる。このように，現行の耐震 設計の考え方では, 全く同じ性能と評価される全 27 ケースの応答が 柱梁接合部の設計が異なるだけで，これほど著しく異なることが確 かめられ，耐震設計に取り入れて考慮すべき極めて重要な結果が得 られているものと言える。

\section{(3) 層間変形の集中と倒壊余裕度}

これまでの検討では，入力倍率が 1.0 の地震応答について比較を したが，ここでは，入力倍率を 0.1 から 1.5 まで変化させ，地震動 レベルごとの最大層間変形角から倒壊余裕度について定量化を試み る。入力地震動は, 既に述べた 5 種類の模擬地震動である。なお, 入力倍率を大きくしていくと, ある層において層間変形角の急増と ともに層間の鉛直方向の距離がゼロ，すなわち柱が横倒しになる場 合が出てくるので，これを崩壊に至ったと判断し解析を打ち切る。

入力倍率と最大層間変形角の関係を Figure 9 に示す。入力倍率が 0.5 ではケースごとの最大層間変形角の差はほとんどない。4 層建物 では 1.5\%から 2.0\%，8 層骨組では 1.0\%，12 層骨組でも 0.5\%から $1.0 \%$ 程度で安定している。入力倍率が 0.5 より大きいと入力地震動 によっては, タイプ| やタイプ|| では最大層間変形角が大きくなる。 例えば入力倍率 1.0 では，4層建物で最大層間変形角が $8 \%$ を超え, 8 層骨組と 12 層骨組ではEI Centro 位相と Hachinohe位相で応答が大 きく，層間変形角が 7\%を超える。しかし，タイプ川I゙は，最大層 間変形角は $2.0 \%$ 程度となっている。入力倍率が 1.0 を超えてもタイ プIII では柱梁接合部の変形角の増大は生じていないことがわかっ ている。つまり，タイプ川川の骨組では，地震動の種類によらず入 力倍率が 1.3 程度までは層間変形のばらつきは抑制され, 最大層間 変形も $2.0 \%$ 程度で高い倒壊余裕度を有しているものといえる。一方 タイプ | やタイプ || では, 入力倍率が 1.0 より小さくても最大層間 変形角が $4 \%$ から $5 \%$ を超える応答となることが推定される。したが って同じ骨組であっても，柱梁接合部の耐震設計によっては，倍率 0.5 を超える地震動に対する損傷制御性能や倒壊余裕度には極めて

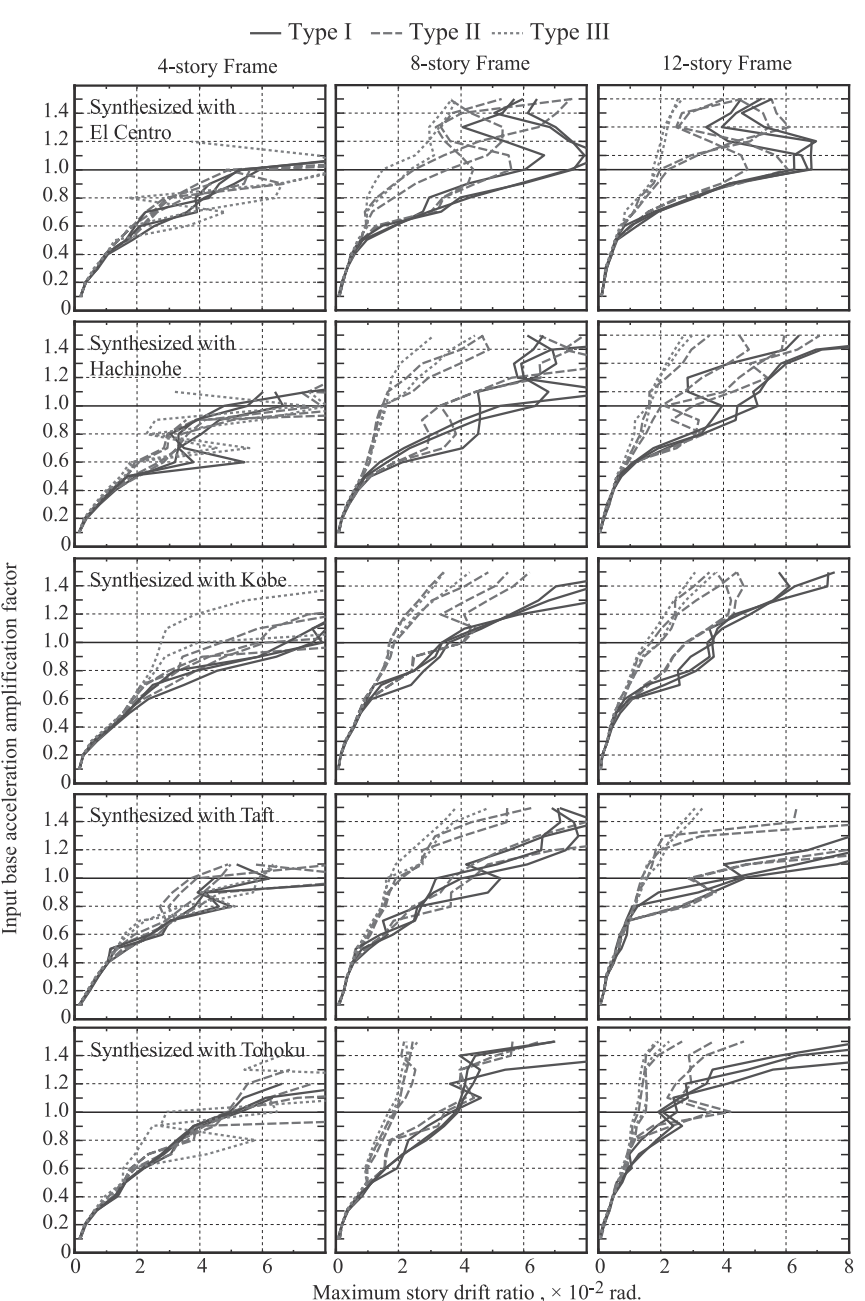

Fig. 9 Result of IDA analyses for maximum story drift with five synthesized input ground motions

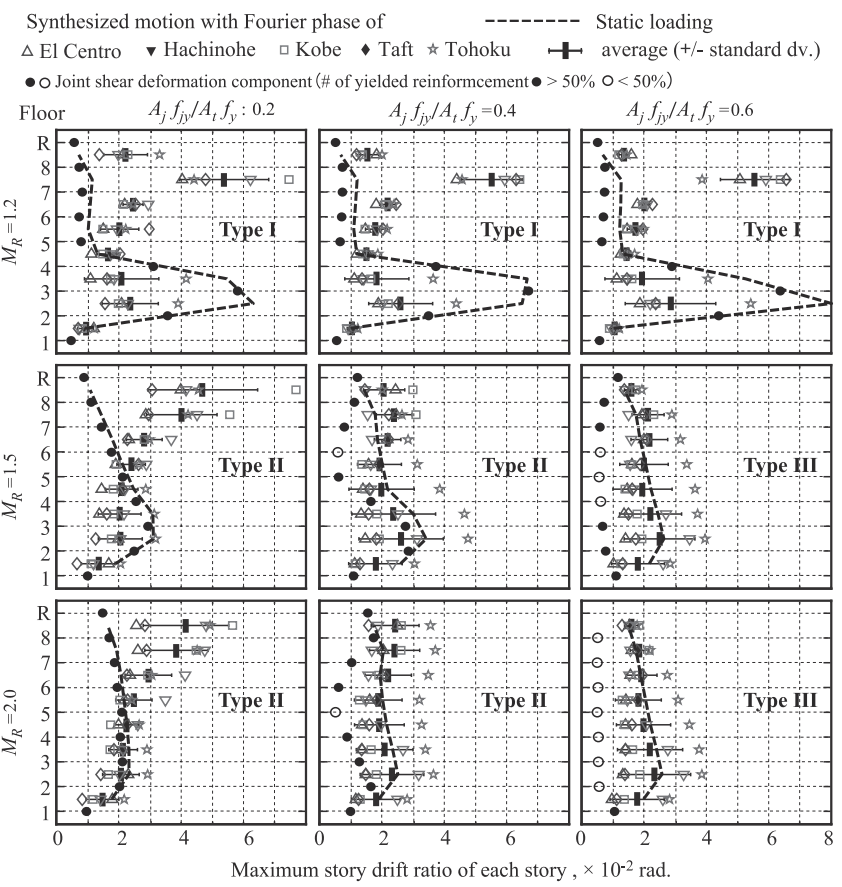

Fig. 10 Attained maximum story drift in dynamic response with excitation of observed base acceleration record normalized by maximum velocity of $100 \mathrm{kine}$ 
大きな差があることがわかる。

\section{（4）観測地震動入力時の変形分布}

次に, 8 層建物の観測波 5 波入力時の各層の最大層間変形角の分 布と柱梁接合部の変形角を Figure 10 に示す。観測波入力時には，8 層建物の模擬地震動入力時と同様に, タイプ।のケースでは, 接合 部横補強比によらず 7 層目に著しく最大層間変形角が集中し，また タイプ II でも接合部横補強比が 0.2 のケースでは上層の最大層間変 形角が，平均して $4 \%$ を超えており，応答が大きくなっている。

残りのタイプ II とタイプIIIでは, 最大層間変形角の 5 波の平均 值は, タイプ।よりも小さく $3 \%$ よりさくなっている。しかし, 5 波の最大值は必ずしも小さくない。中でも，Tohoku と Hachinohe 波 の応答はどのケースでも $4 \%$ 程度に達している。これは，模擬地震 波入力時と異なる傾向といえよう。観測波応答では, 入力地震動の スペクトル特性が異なるため, 柱梁接合部のタイプによる剛性低下 の進行の違いと，地震動の位相特性の影響を受けるためと考えられ る。

このことから，最大層間変形角は，タイプによらず入力地震動に よる応答の変動が大きいが相対的には，タイプ II とタイプ III の応 答はタイプ | に比べればそのばらつきが小さい。一方，タイプ III では, タイプ|やタイプ|| と異なる点は, 柱梁接合部は弾性範囲 に止まっている点で，柱梁接合部の損傷は避けられるものと考えら れる。

\section{(5) 変形集中層の柱梁接合部の配筋変更による応答低減と均一化}

模擬地震動 5 波を入力した 8 層建物の応答では, タイプ।や夕 イプ II の場合, 7 層目に最大層間変形角が集中し変形集中率が大き くなったことは, Figure 8(b) に示したとおりである。そこで，8層 骨組全てのケースについて, $7 \cdot 8$ 階床の柱梁接合部で接合部降伏が 起こらないように，その接合部横補強比を 0.6 に, 柱主筋量を増加 させて柱梁強度比を 2.0 となるように強化した場合，最大層間変形 角が，どのようになるか検討し，その結果をFigure 11 に示す。

タイプ I を強化した場合では, 基準建物よりは応答は小さくなる ものの，逆に中層および下層の最大層間変形角が大きくなるなど， 変形集中層が強化していない層に移動した。一方でタイプ川の接合 部横補強比が 0.2 のケースでは, 上層の最大層間変形角が抑制され, 最大層間変位は各層である程度一様となり変形集中は緩和された。 タイプ IIIでは強化しても仕様が元とほとんど変わらないため, 最 大層間変形角はほぼ同じとなっている。

従って，タイプI では，変形が集中した層の上下階の柱梁接合部 の夕接合部降伏を防止する設計としても，特定層への変形集中は防 止できない。タイプ II では変形が大きかった層の上下階の柱梁接合 部さえ強化すれば，上層の変形が抑制された各層である程度一様な 分布とすることができる。

しかしながら, 観測地震動による応答を示した Figure 10 のように, 一般にどの部分に応答変位が集中寸るかは，地震動の周期特性と位 相特性により変化するので，地震動が特定されない一般の耐震設計 において，一部の柱梁接合部のみを補強して層間変形がどの層にも 集中しないようにすることは困難である。

\section{8. 解析結果の検討と現行の耐震設計法への示唆}

梁曲げ降伏もしくは接合部降伏する鉄筋コンクリート造骨組を対

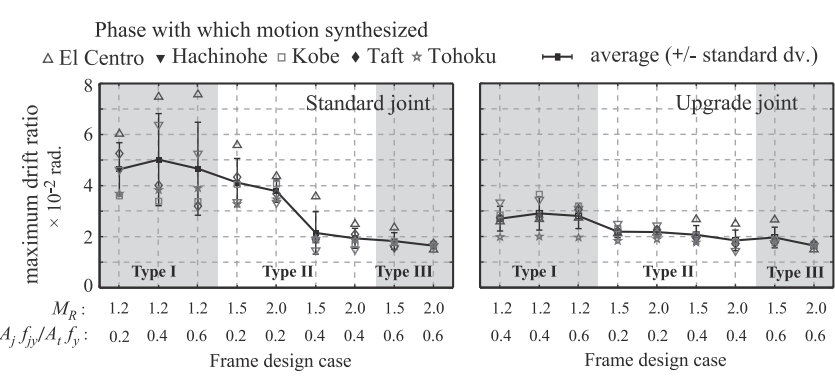

Fig. 11 Attained maximum story drift in dynamic response of frame with upgrade beam-column joint

象として, 柱梁強度比と接合部横補強比を変数とした地震応答解析 を行って得られた解析結果を以下に要約する。

柱梁接合部の接合部降伏は，頂部の変位応答のわずかな増大を引 き越こし,一部の層に層間変形に集中を引き起こした。その原因は, 柱梁接合部内の主筋の降伏と斜めひび割れの開閉により，剛性低下 層が発生し, 振動モードが変化して, 剛性の急変した層に変形が進 み，接合部降伏による耐力劣化が，それを加速したためと考えられ る。

柱梁強度比が 1.2 では, 接合部の横補強筋量に関わらず特定層へ の著しい変形集中が生じた。特定層への変形集中は, P-デルタ効果 により構造物が倒壊する原因となり耐震設計上極めて望ましくない。 また, 柱梁強度比が 1.2 では変形が集中する層の上下階の柱梁接合 部の夕接合部降伏を防止しても他の柱梁接合部の変形が増大し変形 が集中するため，一部の接合部降伏の防止では特定層への変形集中 は防止できなかった。

柱梁強度比が 1.5 未満もしくは接合部横補強比が 0.4 程度以下の 場合には, 変形が集中寸る層は静的解析と地震応答解析では異なっ た。さらに，入力地震動によっても接合部降伏する柱梁接合部およ び変形が集中して増大する層は異なった。接合部降伏する動的応答 では, 接合部降伏する骨組の高さ方向の最大応答層間変形分布には, 地震動によりばらつきが見られ，これを，梁曲げ降伏しか考慮でき ない従来の静的漸増載荷解析の架構モデルを使って推定することは 極めて困難だと思われる。そのため, 一自由度に縮約して簡略的に 地震応答を推定する等価線形化法や, 柱梁接合部の変形を, 梁端の 曲げバネにスリップで考慮する骨組の時刻歴応答解析法などの従来 の方法では, 応答を極めて小さく評価する可能性が高く, やはり適 切に地震応答を推定することは困難である。

柱梁強度比が 1.5 を超え, かつ, 接合部横補強比が 0.4 程度以上 では接合部降伏は発生するものの特定層への変形集中はある程度回 避でき,さらに接合部横補強比を 0.6 とすることにより接合部降伏 も防止できる。部分的には柱梁強度比が 1.5 であっても, 変形の増 大箇所の柱梁強度比を 1.5 から 2.0 に, 接合部横補強比を 0.6 にす ることにより各層一様な変形分布とすることができ, この接合部降 伏の防止により他の柱梁接合部の接合部降伏が誘発されることもな かった。

変形集中層の柱梁接合部の柱梁強度比と接合部横補強筋量を増や して梁降伏するよう設計変更すると, ある程度層間変形集中を減ら すことはできた。しかし, 異なる地震動に対しても, 確実に特定層 地震応答の増大を防ぐために, 全層に渡って柱梁接合部を接合部降 伏しないようにする設計が必要であろう。 


\section{9. 結論}

鉄筇コンクリート造骨組の非線形時刻歴地震応答解析を行い, 接 合部降伏する柱梁接合部の特性が最大層間変形角に及ぼす影響を検 討して, 現行の純ラーメン骨組の柱梁接合部の耐震設計上の課題を 検討した。接合部降伏する柱梁接合部を含む多層骨組の応答では, 塑性域に入る大地震の入力時には，上層の特定の層付近で層間変形 の振幅中心が一方向に流れて増大寸るむち振り現象が現われること が見られた。従来の梁端部の曲げ降伏しか考慮しない骨組モデルで はそのような現象は再現できない。全体降伏型に設計されることが 前提とされている勒性骨組架構による鉄筋コンクリート多層骨組の 現行の耐震設計規定では，法令・学会規準指針を問わず，確実に柱 梁接合部の接合部降伏を避けるための規定が不備であることは大き な問題であるが, 建築構造設計者も, 基準化を待つのではなく, で きるところから早急に対応が行われることが推奨される。

\section{謝辞}

本研究は, 平成 25 27 年度科研費基盤研究(B)（接合部破壊型の 柱梁接合部を含む多層鉄筋コンクリート造骨組架構の耐震設計法 課題番号 25289179 研究代表者：塩原等）により行われた。

\section{参考文献}

1) Structural Committee of AlJ : AlJ Standard for Lateral L oad-carrying Capacity Calculation of Reinforced Concrete Structures (D raft), A rchitectural Institute of Japan, 2016. 4 (in Japanese)

日本建築学会構造委員会 : 鉄筋コンクリート構造保有水平耐力計算規準 (案) ・同解説, 日本建築学会, 2016.4

2) Nagae T. et al.: Large-scale Shaking Table Tests on a Four-story RC Building, Journal of Structural and Construction Engineering (Transactions of AlJ), Vol. 76, N o. 669, pp. 1961-1970, 2011. 11 (in Japanese)

長江拓也，田原健一，福山國夫，松森泰造，塩原等，壁谷澤寿海，河野進， 西山峰広，西山功: 4 階建て鉄筋コンクリート造建物を対象とした大型振 動台実験, 日本建築学会構造系論文集，第 76 巻，第 669 号, pp. 1961-1970, 2011. 11

3) Kajiwara K. et al.: Three-dimensional shaking table test of 10 story RC frame (2015) at E-defense, Summaries of Technical Papers of Annual Meeting, A rchitectural Institute of Japan, Structure IV, pp. 871-872, 2016. 8 (in J apanese) 梶原浩一，土佐内優介，佐藤栄児，福山園夫，井上貴仁，塩原等，壁谷津 寿海，長江拓也，福山洋，壁谷津寿一，向井智久：E ディフェンスを用い た 10 階建鉄筋コンクリート造建物 (2015)の三次元振動台実験 その 5 基 礎す心゙りと試験体損傷の考察, 日本建築学会大会学術講演梗概集構造IV, pp. $871-872,2016.8$

4) Satoh $Y$. et al.: Influence of Joint Hinging on Seismic Response of 8-story Reinforced Concrete Moment Resisting Frames, Summaries of Technical Papers of A nnual Meeting, A rchitectural Institute of Japan, Structure IV, pp. 151-154, 2015. 9 (in Japanese)

塩原等，佐藤友佳，楠原文雄 : 接合部降伏する鉄筋コンクリート造 8 層骨 組の弾塑性地震応答解析 (その 1-2), 日本建築学会大会学術講演梗概集 構造 IV, pp. 151-154, 2015. 9

5) Kobayashi F. et al.: Influence of J oint Hinging on Seismic Response of 12-story Reinforced Concrete Moment Resisting Frames, Proceedings of the 12th A nnual M eeting of J apan A ssociation for Earthquake Engineering, P1-12, 2016 9 (in J apanese)

小林楓子, 佐藤友佳, 楠原文雄, 塩原等 : 接合部降伏する鉄筋コンクリ 一下造 12 層骨組の地震応答解析, 日本地震工学会・大会 2016 梗概集, P1-12, 2016. 9

6) Eto H. and Takeda J.: Elast-plastic Earthquake Response Analysis of Reinforced Concrete Structure, Summaries of Technical Papers of Annual M eeting, A rchitectural Institute of J apan, pp. 1877-1878, 1977. 10 (in Japanese) 江戸宏彰, 武田寿一：鉄筋コンクリート構造物の弾塑性地震応答フレー 厶解析, 日本建築学会大会学術講演梗概集, pp. 1877-1878, 1977. 10

7) Lopez O., Otani S. and A oyama H.: Influence of M ember Hysteretic Shape on Non-linear Earthquake Response, Proceedings of Annual Convention, Japan
Concrete Institute, Vol. 12, N o. 2, pp. 113-118, 1990. 6 (in J apanese) Oscar Lopez, 小谷俊介, 青山博之: 骨組の非線形応答に及ぼす部材履歷 形状の影響，コンクリート工学論文集，第 12 巻 2 号, pp. 113-118, 1990. 6

8) Kawamura F. and Yoshimura M.: Earthquake Response Analysis of R/C Structure Considering Slip B ehavior, Summaries of Technical Papers of A nnual M eeting, A rchitectural Institute of J apan, pp. 753-754, 1998. 9 (in J apanese) 川村文雄, 芳村学：スリップ性状を考慮した鉄筋コンクリート建物の地 震応答解析, 日本建築学会大会学術講演梗概集, pp. 753-754, 1998. 9

9) Horii $Y$. and Kabeyasawa T.: Influence of Hysteretic Energy Dissipation Capability of RC Building on Seismic Response, Proceedings of Annual Convention, Japan Concrete Institute, Vol. 21, No. 3, pp. 13-18, 1999.6 (in Japanese)

堀井良浩, 壁谷澤寿海： RC 建物の地震応答に及ぼす履歴エネルギー吸 収性能の影響，コンクリート工学年次論文報告集，第 21 巻，第 3 号, pp. 13-18, 1999.6

10) Tei B., Maeda M. and Nagata S.: Influence of Hysteretic Energy Dissipation Capability and Strength degradation on RC Building on Seismic Response, Proceedings of A nnual Convention, J apan Concrete Institute, Vol. 22, N o. 3, pp. 37-42, 2000. 6 (in J apanese)

鄭文淑, 前田匡樹, 長田正至 : 部材の履歴特性における耐力低下及びス リップ形状が RC 構造物の地震応答に及ぼす影響, コンクリート工学年 次論文報告集，第 22 巻，第 3 号，pp. 37-42, 2000. 6

11) Kuramochi et al.: Study on Seismic Response Characteristic of High-Rise Reinforced Concrete Structures Subjected to Repeatedly Loading Hysteresis Part 6, Summaries of Technical Papers of Annual Meeting, A rchitectural Institute of J apan, Structure IV, pp. 565-566, 2015. 9 (in Japanese)

倉持真也他：多数回繰り返し履歷を受ける超高層鉄筋コンクリート造建 築物の応答性状に関する研究 (その 650 階骨組モデルの地震応答解析), 日本建築学会大会学術講演梗概集構造 IV, pp. 565-566, 2015. 9

12) Gian Michele Calvi, Guido Magenes and Stefano Pampanin: Relevance of B eam-column J oint Damage and Collapse in RC Frame A ssessment, Journal of Earthquake Engineering, Vol. 6, Special Issue 1, Imperial College Press, pp. 75-100, 2002

13) Kusuhara F., Kim S. and Shiohara H.: Seismic Response of Reinforced Concrete M oment Resisting Frames of B eam-column J oint $Y$ ielding, J ournal of Structural and Construction Engineering (Transactions of AlJ), Vol. 78, N o. 686, pp. 847-855, 2013. 4 (in J apanese)

楠原文雄, 金秀禧, 塩原等 : 接合部降伏する鉄筋コンクリート造骨組の 地震応答解析，日本建築学会構造系論文集，第 78 巻，第 686 号，pp. 847-855, 2013. 4

14) Kim S., K usuhara F. and Shiohara H.: Seismic Collapse Limit of M ulti-story RC Fish B one Structure, Proceedings of A nnual Convention, Japan Concrete Institute, Vol. 36, N o. 2, pp. 247-252, 2014. 6 (in Japanese) 金秀禧，楠原文雄， 塩原等：地震動を受ける RC 造魚骨形多層骨組の余震時の倒壊限界, コ ンクリート工学年次論文集，第 36 巻，第 2 号, pp. 247-252, 2014. 6

15) Shiohara $H$., Satoh $Y$. and K usuhara F.: Influence of J oint Hinging on Seismic Response of 8-story Reinforced Concrete Moment Resisting Frames, Summaries of Technical Papers of Annual Meeting, A rchitectural Institute of Japan, Structure IV, pp. 151-154, 2015. 9 (in Japanese) 塩原等, 佐藤友佳, 楠原文雄 : 接合部降伏する鉄筋コンクリート造 8 層 骨組の弾塑性地震応答解析, 日本建築学会大会学術講演梗概集, pp. 151-154, 2015. 9

16) Architectural Institute of Japan: Guidelines for Seismic Design of Ductile R einforced Concrete Structure and Commentary, A IJ, 1990 (in J apanese) 日本建築学会 : 鉄筋コンクリート造建物の勒性保証型耐震設計指針・同 解説, 1990

17) Neuenhofer, A and Filippou, F. C.: Evaluation of N onlinear Frame Finite Element M odels, J ournal of the Structral Engineering, A SCE, Vol.123, N 0.7, pp.958-966, 1997. 7

18) Takeda, T., Sozen, M. A . and Nielsen, N. N.: Reinforced Concrete Response to Simulated Earthquakes, Journal of the Structural Division, A SCE, V ol. 96, No. 12, pp. 2557-2573, 1970. 12

19) Nakamura, H., and Higai, T.: Compressive Fracture Energy and Fracture Zone Length of Concrete Modeling of Inelastic Behavior of RC Structures under Seismic Loading, Modeling of Inelastic Behavior of RC Structures under Seismic Loads, A SCE, pp. 471-487, 2001

20) Park R. and Dai Ruitong: A Comparison of the Behaviour of Reinforced Concrete Beam-column Joints Designed for Ductility and Limited Ductility, Bulletin of the New Zealand National Society for Earthquake Engineering, $\mathrm{V}$ ol. 21, No. 4, pp. $255-278,1988.12$ 


\title{
EARTHQUAKE RESPONSE OF MULTI-STORY REINFORCED CONCRETE PLANE FRAME STRUCTURES AND SEISMIC DESIGN OF BEAM-COLUMN JOINTS
}

\author{
Hitoshi SHIOHARA*, Fuko KOBAYASHI**, Yuka SATO** \\ and Fumio KUSUHARA***
}

\author{
* Prof., Dept. of Architecture, School of Engineering, the University of Tokyo, Dr. Eng. \\ ** Former Grad. Students, Dept. of Architecture, School of Engineering, the University of Tokyo \\ *** Assoc. Prof., Dept. of Architecture and Design, Civil Eng. and Industrial Management Eng., Nagoya Institute of Technology, Dr. Eng.
}

Non-linear time history earthquake response of reinforced concrete multi-story moment resisting frame structures are calculated with a model of beam-column joints considering their restoring force characteristics which represents the interaction of moment, axial force and shear (Figure 1). The influence of the failure mechanism and strength degradation of beam-column joint are investigated by the comparison of the simulation of twenty-seven model frames (Table 1) satisfying the current seismic provisions in Japan, the model parameters for which are combination of column-to-beam strength ratio of $1.2,1.5$, and 2.0 and joint hoop reinforcement ratio of around $0.2 \%$ to $0.6 \%$ which are neglected as design parameters affecting the seismic safety in design practice in Japan. Statically cyclic response analyses of the model frames subjected to lateral load distribution pattern of Ai by displacement control at the top floor are calculated to classify the type of hysteresis loop and strength degradation (Figure 3). Then dynamic analyses of the model frames are carried out subjected to five artificial base ground motions conformed to maximum considered intensity design (MCD) spectrum and five observed strong motions (Figure 4). It is found that there is significant difference in the story drift response of the structures with different beam-column joint attributes. Particularly, in some cases, the story drift ratio increased significantly due to concentration of lateral deflection to several stories and large residual drift remains to one direction (Figure 5). It is confirmed that the differences are due to softening of stiffness and strength degradation of the beam-column joints. It is caused by the mechanism identified as joint hinging (ref. 1) which features the yielding of longitudinal reinforcement within the beam-column joint and repetition of diagonal crack open and close. The state-of-the-practice analytical model for frames does not consider the joint hinging so it significantly underestimates the story drift responses by far than seismic design criteria (Figure 8). The response of frames with beam-column joint failing in joint hinging is very sensitive to base ground motions which were synthesized with same target response spectrum. So the prediction of the response is difficult by non-linear static procedure nor non-linear time history procedure the model of which consider plastic deformation only by non-linear rotational springs at beam-ends considering hysteresis model with slip behavior. The results of incremental dynamic analysis (IDA) shown in Figure 9 reveals that the amplification less than 50\% of MCD yields little difference in the response of the models whilst the amplification of $100 \%$ of MCD causes near collapse to four-story model and concentration of story drift exceeding $6 \%$ to the models failing in joint hinging mechanism, which is far beyond seismic design criteria for MCD. The current Japanese seismic design practice for beam-column joint obviously lacks the necessary reinforcing detailing provision such as minimum column-to-beam strength ratio and design of required joint hoop ratio which is much behind the seismic provisions found in current NZ3101 and ACI 318 building codes.

(2017 年 4 月 5 日原稿受理, 2017 年 6 月 1 日採用決定) 